\title{
The Relationship between International Law and Domestic Law under the Constitution of the Republic of Kosovo
}

\author{
Dr. Jordan Daci \\ Tirana, Albania \\ jordan.daci@gmail.com
}

Doi:10.5901/ajis.2015.v4n1s2p81

\begin{abstract}
The relationship between international law and domestic law is object of different theories among which the most relevant are: the Monist Theory, Monist Inverse Theory, Dualist Theory, and Harmonization Theory. Indeed, these theories and all the other theories, aim nothing more or less than the explanation of the interdependent and hierarchical relationship between the international law and domestic law. Indeed, the study and the analysis of relationship between the rules of international law and rules of domestic law has a particular importance, because the determination of solutions and dilemmas in regards to this multiple and multidimensional relationship inter alia defines the statues of the state in the arena of the international relation, and impacts directly to its status as an equal member of international community. In fact, the ensemble of rules which we define today as International Law cannot be understood separated from the states domestic law. In reality, these two categories of legal rules are essentially interrelated in a hierarchical manner. Borders and content of the states domestic law systems, today very often are defined in almost natural manner by the rules of the International Law, which gradually have ensured a sustainable prevalence upon the rules of Domestic Law. Regardless of differences from a state to another, even in the case of the Republic of Kosovo, in essence the relationship between International Law and Domestic Law, consists inter alia in four main issues such as: 1. The relationship between rules of International Customary Law and the Domestic Law; 2. The relationship between the rules of International Treaties and the Domestic Law; 3. The relationship between the rules adopted by international organization in which Kosovo would be a member and the rules of Domestic Law; and 4. The relationship between the rules of International law and the Constitution of the Republic of Kosovo itself. This paper aims exactly the analysis of these four issues from a comparative perspective with other states such as: the Republic of Albania, Germany, Netherlands, Italy and the United States of America.
\end{abstract}

Keywords: Theories of international law, International Law vs. Domestic Law, Kosovo, Supremacy of International Law, International Customary Law, hierarchy of legal norms

\section{Introduction}

The study and the analysis of the relationship between the rules of international law and rules of domestic law has a particular importance, because the determination of solutions and dilemmas in regards to this multiple and multidimensional relationship inter alia defines the statues of the state in the arena of the international relation, and impacts directly to the status of the state as equal member of international community. In case of the Republic of Kosovo, the acceptance and the implementation of the International Law in prevalence vis-à-vis Domestic Law, is a necessity and perquisite inter alia for the internationalization of the new born state of Kosovo, which cannot be an equal member of the international community if does not accept and apply the international law, thanks to which the international community itself exist and function. Today, more than ever, a significant of International Law rules implies direct effects to states and individuals without needing any intervention of rules of the Domestic Law. In the groups of such rules belong especially the rules of the International Human Rights Law, which in one hand guarantee rights to individuals and on the other hand, imply obligations to state. In case of Kosovo, its constitution has directly called upon and has integrated in its text some of the most important acts of International Human Rights Law such as: The Universal Declaration of Human Rights; (2) The European Convention for the Protection of Human Rights and Fundamental Freedoms and its protocols thereto; (3) International Covenant on Civil and Political Rights and its protocols thereto; (4) Council of Europe Framework Convention for the Protection of National Minorities; (5) The Convention on the Elimination of all forms of Racial Discrimination; (6) The Convention on the Elimination of all forms of Discrimination against women; (7) Convention on the Rights of the Child; (8) Convention against Torture and Other Cruel, Inhumane or Degrading Treatment or Punishment. These important sources of the International Human Rights Law, not only are constituent part of the Constitution, but 
serve also as a criterion and evaluation parameter for the all the rest of norms of the Constitution and other acts enacted pursuant to the Constitution. Furthermore, the particular nature of the state organization of Kosovo and the implemented state model, impacts directly to the relationship between the International Law and Domestic Law transforming it into a sui generis case not only from the perspective of particular legal framework regime, but also from a practical point of view. Moreover, the status of Kosovo as an independent state, but not yet a member of the key international intergovernmental organization such as: UN. CoE, OSCE etc, vis-à-vis unilateral acceptance of the most relevant sources of international law has a particular importance for a more essential study of this relationship.

\section{The Relationship between Rules of International Customary Law (or General International Law) and Rules of Domestic Law}

The Constitution of the Republic of Kosovo (hereinafter the Constitution) does not contain a precise formulation concerning the relationship between rule of International Customary Law and rules of Domestic Law differently from the case of the Federal Republic of Germany, or the Republic of Italy, where it is clearly foreseen the prevalence of rules of International Customary Law vs. rules of Domestic Law. Specifically, the German Constitution in the Article 25 foresees that: Article 25 (Public international law and federal law) "The general rules of public international law form part of the Federal law. They take precedence over the laws and directly create rights and duties for the inhabitants of the Federal territory", while the $1^{\text {st }}$ paragraph of the Article 10 of the Italian Constitution foresees that: "The Italian legal system conforms to the generally recognized principles of International law". Meantime in case of Kosovo, specifically the Constitution in the Article 16 defines that: "The Republic of Kosovo shall respect International Law". As it is clearly visible, this is a very general formulation, which clearly indicates that its content is an influence of the formulation of the Article 5 of the Constitution of the Republic of Albania where it is defined that: "The Republic of Albania applies International Law that is binding upon it". Certainly it is clear that a general formulation such as in the case of Albania has been accepted raises discussion upon unclear issues such as if this formulation applies sole for international treaties which are ratifies by the People's Assembly in accordance to the article 18 and 65 of the Constitution, or if this article defines that Kosovo respects also other rules of International Law deriving from other sources such as: Customs, General principles, opinio juris etc. In follow, the Constitution provides inter alia in the Article 53 that: "Human rights and fundamental freedoms guaranteed by this Constitution shall be interpreted consistent with the court decisions of the European Court of Human Rights". In other words, it is clear that the Article 53 accepts directly as a binding source of the International Law [part of which is also the European Convention for the Protection of Human Rights and Fundamental Freedoms (Hereinafter ECHR)] also the judgments of the European Court of Human Rights (Hereinafter ECtHR), which do not derive directly from treaties. On the other hand, the exact meaning of the Article 16/3 can be understood sole in wider context, as long as it is well known that states are obliged to respect and to accept rules of International Law that are binding upon them, but which do not derive necessarily from treaties and for which no expression of any consent to be bound by a treaty is required. In this category of rules, belong first the rules of International Law which are classifies as jus cogens or peremptory norms of international general law and consist of norms accepted and recognized by the entire international community of states as a norm from which no derogation is permitted and which can be modified only by a subsequent norm of general international law having the same character. This definition is made in the Article 53 of the Vienna Convention on the Law of Treaties which foresees that: "A treaty is void if, at the time of its conclusion, it conflicts with a peremptory norm of general international law. For the purposes of the present Convention, a peremptory norm of general international law is a norm accepted and recognized by the international community of States as a whole as a norm from which no derogation is permitted and which can be modified only by a subsequent norm of general international law having the same character". From this point of view, we have the right to raise the question: how can we accept the idea that these norms are not binding to a state, when the validity of the norms of international treaties signed and ratified by a state is precisely defined by these norms? Thus, this Article can be interpreted just in such manner which would guarantee the recognition and supremacy of the Jus Cogens norms, because the latter enjoy the status of the supreme norms in relationship with the states Domestic Law of international community members. ${ }^{1}$ Such idea is supported also by professor Xhezahir Zaganjori who further clarifies that, taking into account the main sources of international law, I would think that within the notion of "the binding International Law", to a state, would belong not only the norms which derive

1 See Article 64 of the Vienna Convention on the Law of Treaties. 
from treaties, but also general norms of international law as well as the general principle of the international law. ${ }^{2}$ In regards to this issue, it should be emphasized the fact that jus cogens norms can be also part of treaties' content. Such statement has been made also in the interpretation of the German Constitutional Court which has emphasized that: in the group of general norms of international law shall be understood before all, norms with normative character that are into force, but not the norms that derive from treaties that define the rules for the settlement of specific cases, meantime according to this court, exceptionally in this group can belong also norms deriving from international agreements with the condition that such norms shall be interpreted or included in the system of norms of the International Law (BVefG 15, 32ff ${ }^{3}$. Similar formulation is also made in the Article 38 of the Vienna Convention on the Law of Treaties titled "Rules in a treaty becoming binding on third States through international custom", in which is further foreseen that "Nothing in articles 34 to 37 precludes a rule set forth in a treaty from becoming binding upon a third State as a customary rule of international law, recognized as such". Moreover, according to the opinion of judge Christopher Weeramantry, stated in his dissenting opinion in the case "Nicaragua vs. USA", by referring to the Advisory opinion of the Court on the "Nuclear weapons" he thinks that: "A generally accepted test for the recognition of the rules of International Customary Law is that such rule should be as widely and generally accepted as its very difficult to presume that a civilized state does not recognize such rule"4. According to him, this statement is supported also by the practice of the majority of the states and by opinio juris. The expression way of consent to be bound by a norm of International Customary Law by ratifying or not an international treaty, has been accepted also International Court of Justice (Hereinafter ICJ) in the "Asylum case", where the court has emphasized that Peru is not obliged to apply a norm which can be part of the International Customary law, because Peru has not ratified a convention in which this norm was included. Consequently, Peru has been considered as a Persistent objector ${ }^{5}$. Furthermore, the Article 38 of the ICJ Statute indirectly defines an international custom as evidence of a general practice accepted as law. This interpretation of the Article 16/ 3 of the Constitution is correct if we take into account the fact that the clause US Constitution is several times less clear that what this article foresees, while the context in which this article has been written and interpreted is completely in favor of the International Law. Similarly, also formulations of other world's constitutions which are interpreted in favor of the International law use more or less the same language. Thus, it would have been absurd for us to interpret today Article $16 / 3$ in a stricter manner than the current interpretation of the Section 8 of the Article 1, of the US Constitution adopted in the year 1787, which indeed contains a formulation several time less favorable than this article concerning the acceptance and the respect of norms of International Customary Law. Concretely, this Article of US Constitution foresees that the Congress shall have the power to define and punish piracies and felonies committed on the high seas, and offences against the law of nations, which at that time was composed almost exclusively by international customs. As stated in the first chapter, regardless of this vague formulation, the US courts and the US Supreme Court practice, beside the fact that are considered as the most conservative courts, again have accepted that such formulation of the Article 1 of the Constitution renders the International Customary Law part of the law of the land. Finally, we can state that the Article $16 / 3$ accepts as binding all the norms of international law that are legally binding, including the norms of the International Customary Law as well as general principles of the International Law, because the Article 19/2 foresees that: "Ratified international agreements and legally binding norms of international law have superiority over the laws of the Republic of Kosovo." This certainly means that in the category of legally binding norms belong also the norms of International Customary Law and the general principles of International Law.

\section{The Relationship between the Norms of International Treaties and the Norms of Domestic Law}

Today, the International Law is considered by many scholars as the "common language" of national courts. ${ }^{6}$ Indeed, as it was stressed out above, today in our globalized world in the presence of a significant international economic

\footnotetext{
2 Xhezahir Zaganjori. "Vendi i së Drejtës Ndërkombëtare në Kushtetutën e Republikës së Shqipërisë”. Journal of the Magistrates School of the Republic of Albania Jeta Juridike. No.2. Tirana, February 2004. pp 30, 31.

${ }^{3}$ Cited by Xhezahir Zaganjori in. "Vendi i së Drejtës Ndërkombëtare në Kushtetutën e Republikës së Shqipërisë". Journal of the Magistrates School of the Republic of Albania Jeta Juridike. No.2. Tirana, February 2004. pp 32.

41989 I.C.J Reports 14 (judgment on the Merit of 27 June 1986). For more see Curtis F.J. Doebbler. "International Human Rights Law: cases and Materials". CDP, Special printing. United States of America 2003.

5 Ibid.

${ }^{6}$ Francesco Francioni. "International Law as a Common Language for National Courts". Texas International Law Journal. Vol 36:587, 2001. pp 557.
} 
dependency, traditional distinction among domestic and foreign issues has lost a lot its $19^{\text {th }}$ century clearance. ${ }^{7}$ Today, international treaties play a key role in the coordination and the establishment of international organization, which has raised an inevitable need for a constitutional response from the perspective of their respective members states legal system, by being inevitably more opened towards International Law. ${ }^{8}$ Despite from monist or dualist approaches, in a way or in another, norms of the International Law have became part of the Domestic Law. ${ }^{9}$ At each time when the norms of the International Law became part of the State Domestic Law, raises the issue on what will be the role of domestic courts and other law enforcement state bodies to build up the rule of law in the international relations. Certainly, state attitudes differ from a state to another and distinctions consist in theoretical and practical relationships that are created between the norms of the International Law and the norms of the State Domestic Law.

Concerning this matter, the Constitution foresees in its Article 19/2 that ratified international agreements and legally binding norms of international law have superiority over the laws of the Republic of Kosovo. In follow in the paragraph 1 of this Article is foreseen that: "International agreements ratified by the Republic of Kosovo become part of the internal legal system after their publication in the Official Gazette of the Republic of Kosovo. They are directly applied except for cases when they are not self-applicable and the application requires the promulgation of a law." In this case, the Constitution has defined that treaties shall be directly applicable if they are considered to be self-executable. What means that such thing shall be foreseen by the international treaty itself, but has left no space to declare case by case prior to the expression of the consent to be bound by that treaty, that such treaty shall be considered self-executable or not, just like the USA always does. ${ }^{10}$ This clearly leads us to the conclusion that in this Article, the Constitution has foreseen the prevalence of treaties vis-à-vis laws of the Republic of Kosovo. However, this Article does not define what will be the status of treaties (or agreements) that are not subject to ratification as a mean to express the consent to be bound by, in accordance to the Vienna Convention on the Law of Treaties. Contrary from the perspective of the domestic law, this issue is very clear and resolved from the perspective of International Law, because according to it, concretely the Article 27 the Vienna Convention on the Law of Treaties foresees that, "A party may not invoke the provisions of its internal law as justification for its failure to perform a treaty. This rule is without prejudice to article 46 " which foresees that: "A State may not invoke the fact that its consent to be bound by a treaty has been expressed in violation of a provision of its internal law regarding competence to conclude treaties as invalidating its consent unless that violation was manifest and concerned a rule of its internal law of fundamental importance." This Article further clarifies that: "A violation is manifest if it would be objectively evident to any State conducting itself in the matter in accordance with normal practice and in good faith". Thus, the obligation to respect international treaties which are not subject to ratification is legal not only from the perspective of International Law, but is also logical and in favor of protection of international legality and respects the generally accepted fundamental principle pacta sun servanta. At the end, as argued by representatives of the Monist Theory, an act of International Law shall prevail upon Domestic Law per virtu, because inter alia such act is not a product of a single legislator, but a product of several legislators acting as one. Consequently, the status of such act shall prevail upon the domestic law. Even more, parties to international treaty are free to choose the mean through which they desire to express their consent to be bound by a treaty. Article 11 of the Vienna Convention on the Law of Treaties foresees that: "The consent of a State to be bound by a treaty may be expressed by signature, exchange of instruments constituting a treaty, ratification, acceptance, approval or accession, or by any other means if so agreed". Therefore, this Article not only does not limit the expression of consent to ratification, but in contrary allows any other mean if so agreed beside ratification, acceptance, approval and accession. Thus, concerning the effects and the supremacy of a treaty visà-vis Domestic Law, the mean agreed for the expression of the consent doesn't have any importance.

\section{The Relationship between the Norms Adopted by International Organizations in which the Republic of Kosovo May be a Member State and the Norms of the Domestic Law}

The Article 17 defines that the Republic of Kosovo concludes international agreements and becomes a member of international organizations. Further, in the paragraph 3 of the Article 2, is foreseen that: "The Republic of Kosovo, in order

\footnotetext{
${ }^{7}$ Rober. Schutze. "On 'Middle Ground": The European Community and Public International Law". EUI Working Papers. Law 2007/13. European University Institute Badia Fiesolana. San Domenico di Fiesole. Italy. pp 1.

8 Ibid.

${ }_{9}^{9}$ Francesco Francioni. "International Law as a Common Language for National Courts". Texas International Law Journal. Vol 36:587, 2001. pp 557.

10 For more see the case "Medellin v. Texas", US Supreme Court, examined on 10 October 2007- and judgment dated 25 March 2008.
} 
to maintain peace and to protect national interests, may participate in systems of international security. While in the Article 20 is foreseen that: "The Republic of Kosovo may on the basis of ratified international agreements delegate state powers for specific matters to international organizations. If a membership agreement ratified by the Republic of Kosovo for its participation in an international organization explicitly contemplates the direct applicability of the norms of that organization, then the law ratifying the international agreement must be adopted by two thirds (2/3) vote of all deputies of the Assembly, and those norms have superiority over the laws of the Republic of Kosovo."

Therefore, it is clear that norms adopted by international organization where the Republic of Kosovo will be a member, shall be legally binding and self-executable, subject to requirement that the law which will ratify the membership treaty shall be adopted with the votes of the $2 / 3$ of the People's Assembly members. If such requirement is fulfilled, than such norms shall prevail upon domestic laws. Certainly, this proves that Kosovo has applied a very contemporary approach in regards to sovereignty and its transfer to international organization. However, from the point of view of this articles, we may still raise the question up to what extend can be transferred the sovereignty? To answer to this question we may refer to the case law of the German Constitutional Court concerning the case on Maastricht Treaty, to the case law of the French Constitutional Council, as well as to the case law the Constitutional Court of the Republic of Albania while examining the constitutionality of the Statute of the International Criminal Court. These courts have stated that "...the transfer of sovereignty powers shall be limited up to that extend where the constitutional identity of the state will be in question"'11 (Judgment of 18 October 1993 of the German Federal Constitutional Court on Maastricht Treaty), or"...the transfer of sovereignty powers shall be limited up to that extend where such transfer will undermine the fundamental exercise of national sovereignty "12. (Decision of the French Constitutional Council of 1985). To conclude, according to these case laws, the transfer of sovereign powers to international organization shall not question the constitutional identity of the Republic of Kosovo and shall not be to such extend as to undermine the fundamental exercise of the national sovereignty.

\section{The Relationship between the Norms of International Law and the Constitution of the Republic of Kosovo Itself}

First we should emphasize that the incompatibility of a ratified treaty with the Constitution would be something very unusual for constitutions which do foresee a pre-examination of the constitutionality of an international treaty by the respective constitutional court prior to its ratification by the legislator. In case of Kosovo none of its articles, including the Article 113 of the Constitutions and neither the Law No.03/L-121 on the Constitutional Court of Kosovo, do not provide jurisdiction for the Constitutional Court of Kosovo to examine the constitutionality of an international treaty, prior to its ratification. Even more, neither the Article 31 of the Law on the Constitutional Court and nor the Article 113 of the Constitution do not provide jurisdiction for the Constitutional Court of Kosovo to examine the constitutionality of any treaty neither prior and nor post ratification. The sole reference that might be used just to initiate a post ratification examination of the constitutionality, is the general jurisdiction defined in the Article 113/2/1 which provides to the Constitutional Court the power to examine the constitutionality of laws. In such case, the object of constitutionality examination shall be not the treaty itself, but the law by which this treaty is ratified; regardless of this fact, the grounds for such examination would be the treaty and not the law of ratification. The lack of jurisdiction for a pre-ratification examination is a very serious problem in the Constitution of the Republic of Kosovo and certainly under these circumstances, the possibility to ratify treaties which wouldn't be compatible with the Constitution is much higher than in other countries such as the Republic of Albania, where the Constitutional Court has jurisdiction to examine the constitutional of a treaty, prior to its ratification. For this reason, under these circumstances, there is an enormous probability that in the future, Kosovo courts shall face the issue of non-compatibility of a treaty with the Constitution. Certainly, the solution for this issue would be the use of two parameters already used by the German Constitutional Court and the French Constitutional Council concerning the extension of sovereign powers transfer. Another way for the examination of the constitutionality of international treaties would be the use as a examination and acceptance parameters of the main 8 (eight) international treaties directly integrated in the Constitution by its Article 22, just as the Article 17 of the Constitution of the Republic of Albania does

\footnotetext{
11 Judgment of 12 October 1993 of the German Federal Constitutional Court on Maastricht Treaty. As cited by the Albanian Constitutional Court in its judgment No.186, dated 23.09.2002.

12 Decision of the French Constitutional Council of the year 1985. As cited by the Albanian Constitutional Court in its judgment No.186, dated 23.09.2002. 
with the ECHR. Moreover, while it is true that the Article 16 of the Constitution defines that: "The Constitution is the highest legal act of the Republic of Kosovo. Laws and other legal acts shall be in accordance with this Constitution", just like articles 4 and 116 of the Constitution of the Republic of Albania do, certainly this does not mean that the Constitution has a absolute supremacy over the norms of International Law. Indeed, the Constitution has accepted the norms of International Treaties foreseen in the Article 22 as its constituent part as well as a supreme evaluation parameter for the norms of the domestic law. Additionally, the Article 53 extends this unilateral acceptance of International Law norms by including in this group of norms, also the case law of the ECtHR. In fact, just like in case of the Republic of Albania, the Article 16 of the Constitution of Kosovo has been formulated in a similar way with the Article 94 of the Dutch Constitution in relation with the Article 106 and other articles. Thus, from this perspective, we may conclude that articles 22 and 53 as well as article 20,19, 17 and 2 of the Kosovo Constitution de jure and de facto limit any strict application of the Article 16. Precisely for this reason, in compliance with article 22 and 53, the Constitution of the Republic of Kosovo shall not be the highest legal act, because the highest legal act in the Republic of Kosovo are the 8 (eight) international treaties listed in the Article 22 as long as the application of these treaties shall not violate the above-mentioned principle concerning the extend of sovereign powers transfer. On the other hand, the opposite approach would defend the idea that the general principle embodied in the Article 16 of the Constitution is not undermined by the articles 22 and 53 , because these legal acts do not prevail over the Constitution, as long as they are considered part of it. However, the second approach cannot overturn the first approach as long as the ECHR and all other international treaties listed in the Article 22 are exclusive acts of International Law and do not derive from the unilateral will of the Kosovo People, product of which is the Constitution. This reasoning is also compatible with the Article 27 of the Vienna Convention on the Law of Treaties as well as with the general principle of the International Law, especially with the generally accepted norms of International Law. Article 27 of this convention defines that: "A party may not invoke the provisions of its internal law as justification for its failure to perform a treaty". Indeed, the prior-mentioned parameter is valid and can be used also as a mean to resolve the issue of relationship between the norms of International Law and the Constitution of the Republic of Kosovo itself. In follow of the prior used logic, from the perspective of the articles 26, 27 and 31 of the Vienna Convention on the Law of Treaties, norms of the International Law shall prevail also over the Constitution itself as long as they do not threat the constitutional identity of the country and do not undermine the fundamental exercise of national sovereignty. Although such conclusion would not be easy acceptable by states in general and by the Albanian Doctrine, except for the eight international treaties listed in the Article 22 that are accepted and considered as constituent part of the Constitution, but at the same time they serve also as parameter for the examination of constitutionality of other norms of Domestic Law, including other norms of Constitution itself. This privileged status of legal acts listed in the Article 22, in fact transforms them into the Supreme Law in the Republic of Kosovo, which consequently defines the extend and the limits of application of other norms of International Law. The acceptance of the International Law supremacy over the Constitution itself is also accepted by the article 91-94 of the Dutch Constitution and is de facto and de jure accepted also by the current opinio juris.

\section{Conclusions}

Referring to the above-mentioned discussion and analysis, we may conclude that the Constitution of the Republic of Kosovo has indirectly accepted the supremacy of International Law vs. Domestic Law, including the Constitution itself. In addition, the latter in the Article 22 has integrated into itself eight of the most important treaties of the International Human Rights Law inter alia by not only considering them as its constituent part, but also as validity evaluation parameters for other norms of the Constitution as well as other norms of Domestic Law. Moreover, these treaties serve also as parameters to define the extension and limits of other International Law norms' acceptance. On the other hand, the Constitution does not contain a proper legal regulation concerning its compatibility with the Vienna Convention on the Law of Treaties in relation to the validity and the status of international treaties which according to this Convention are not subject to ratification, but the consent to be bounded by, is express through other means. However, general definitions made in the Constitution in regards to International Law, make legally binding also other norms of International Law that do not derive from international treaties, but derive from International Customary Law as well as general principles of International Law and ensure their supremacy over the domestic law, both from a de facto and de jure perspective. Moreover, we should emphasize the fact that the lack of jurisdiction of the Kosovo Constitutional Court to examine the constitutionality of international treaties prior to their ratification as well as the lack of a clear jurisdiction to make such examination in post ratification period, not only increases the changes to ratify treaties that are not compatible with the Constitution, but make very difficult the job of courts in general and more specifically of the Constitutional Court to come 
up with solutions for such cases. Therefore, in absence of clear and complete definitions on the means to express the consent to be bound by a treaty in compliance with the Vienna Convention on the Law of Treaties, and in absence of Constitutional Court jurisdiction to examine the constitutionality of international treaties prior and in post ratification period, based on the paragraph 10 of the Article 113 of the Constitution, would be strongly recommended the adoption of a specific constitutional law that would define precise and specific rules concerning the signature, accession, approval etc of international treaties as well as would complete the lacking jurisdiction of the Constitutional Court.

Finally we may also conclude that the clauses of the Kosovo Constitution concerning the membership in the international organization as well as the transfer of sovereign powers to international organizations including international bodies on common security, are complete and provide a very contemporary legal regime, which allows the state of Kosovo to be a full and active member of the international community without the need of introducing any constitutional amendment.

\section{References}

Curtis F.J. Doebbler. "International Human Rights Law: cases and Materials". CDP, Special printing. United States of America 2003.

Francesco Francioni. "International Law as a Common Language for National Courts". Texas International Law Journal. Vol 36:587, 2001.

Law No.03/L-121 on the Constitutional Court of the Republic of Kosovo.

Vienna Convention on the Law of Treaties.

Constitution of the Netherlands Kingdom.

Constitution of the Federal Republic of Germany.

Constitution of the Republic of Italy.

Constitution of the Republic of Albania.

Constitution of the Republic of Kosovo.

Constitution of the United States of America.

Case "Medellin v. Texas", US Supreme Court, Judgment of 25 March 2008.

Asylum case.

Case "Nicaragua v. USA".

Rober. Schutze. "On 'Middle Ground": The European Community and Public International Law". EUI Working Papers. Law $2007 / 13$. European University Institute Badia Fiesolana. San Domenico di Fiesole. Italy.

Judgment of 12 October 1993 of the German Federal Constitutional Court on Maastricht Treaty.

Decision of the French Constitutional Council of the year 1985.

Judgment of the German Constitutional Court BVefG 15, 32ff. For more see Zaganjori, 2004.

Xhezahir Zaganjori. "Vendi i së Drejtës Ndërkombëtare në Kushtetutën e Republikës së Shqipërisë". Journal of the Magistrates School of the Republic of Albania Jeta Juridike. No.2. Tirana, February 2004. 
